\title{
New Stratigraphic Rank for the Carboniferous, Mississippian, and Pennsylvanian in Kansas
}

\author{
Robert S. Sawin ${ }^{1}$, Evan K. Franseen ${ }^{1}$, \\ W. Lynn Watney ${ }^{1}$, Ronald R. West ${ }^{2}$, and Greg A. Ludvigson ${ }^{1}$
}

${ }^{1}$ Kansas Geological Survey, 1930 Constant Avenue, Lawrence, Kansas 66047

${ }^{2}$ Emeritus Professor, Kansas State University, Manhattan, Kansas 66506

${ }^{1,2}$ Member, Stratigraphic Nomenclature Committee, Kansas Geological Survey

\begin{abstract}
A new classification for the Carboniferous System/Period is formally adopted by the Kansas Geological Survey (KGS), and Zeller (1968) is modified accordingly. The Carboniferous is the system/period between the Devonian and Permian, and the Mississippian and Pennsylvanian are subsystems/subperiods of the Carboniferous. The Mississippian is subdivided into Lower, Middle, and Upper Mississippian Series and the Pennsylvanian is subdivided into Lower, Middle, and Upper Pennsylvanian Series. Regional stage names remain unchanged.
\end{abstract}

\section{Introduction}

In an effort to standardize international stratigraphic nomenclature globally, the international geoscience community has embraced a new classification for the Carboniferous System/ Period that includes subsystem/subperiod, series/epoch, and stage/age names. This paper addresses the new classification scheme as it applies to Carboniferous nomenclature in Kansas, and subsequent revisions to Zeller (1968) that are hereby formerly adopted by the Kansas Geological Survey (fig. 1).

\section{Discussion}

The term Carboniferous has long been a system/period name in Europe and was used by early workers in North America. R. C. Moore (1935, p. 246-248) editorialized that Carboniferous should be retained as the system/period name for strata between the Devonian and Permian and that Mississippian and Pennsylvanian be classed as "subsystemic divisions" of the Carboniferous, although his publications used the more popular classification of Mississippian and Pennsylvanian as system/ period names. However, consensus for a bipartite classification of the rocks between the Devonian and Permian grew in the published literature. In 1945, the American Association of Petroleum Geologists recognized the Mississippian and Pennsylvanian as systems/periods (Cheney et al., 1945) and reserved the term Carboniferous for informal usage. In Kansas, the current accepted stratigraphic guide and chart (Zeller, 1968) classifies the Mississippian and Pennsylvanian as systems/ periods.

The International Commission on Stratigraphy (ICS), and its parent the International Union of Geological Sciences (IUGS), have ratified a new Carboniferous classification. These changes, and guidelines for their use, are summarized in Heckel and Clayton (2006a, 2006b), shown in Ogg et al. (2008), and appear on the ICS website at http://www.stratigraphy.org/upload/ ISChart2008.pdf.

\section{System/Period}

The Carboniferous is now globally recognized as the system/ period between the Devonian and Permian Systems/Periods.

\section{Subsystems/Subperiods}

The Mississippian and Pennsylvanian are now subsystems/ subperiods of the Carboniferous System/Period. This decision was ratified by the ICS and IUGS and reported in the 2000 Newsletter on Carboniferous Stratigraphy (Metcalfe, 2000). The Global Stratotype Section and Point (GSSP) for the Mississippian-Pennsylvanian boundary was established at Arrow Canyon, Nevada (Lane et al., 1999; Richards et al., 2002).

\section{Series/Epochs}

The Mississippian Subsystem/Subperiod has been subdivided into Lower, Middle, and Upper Mississippian Series (Early, Middle, and Late Mississippian Epochs), and the Pennsylvanian Subsystem/Subperiod into Lower, Middle, and Upper Pennsylvanian Series (Early, Middle, and Late Pennsylvanian Epochs). This was ratified by the ICS and IUGS and reported in the 2004 Newsletter on Carboniferous Stratigraphy (Work, 2004).

\section{Stages/Ages}

The stage/age names used in Russia and Europe were ratified by the ICS and IUGS (Work, 2004) as the official global stage/ age names for the Carboniferous. The stage/age boundaries coincide with the series/epoch boundaries (see fig. 1), in ascending order: Lower Mississippian $=$ Tournaisian; Middle Mississippian = Visean; Upper Mississippian = Serpukhovian; 


\section{Zeller, 1968 KGS Nomenclature, 2009 ICS Nomenclature}

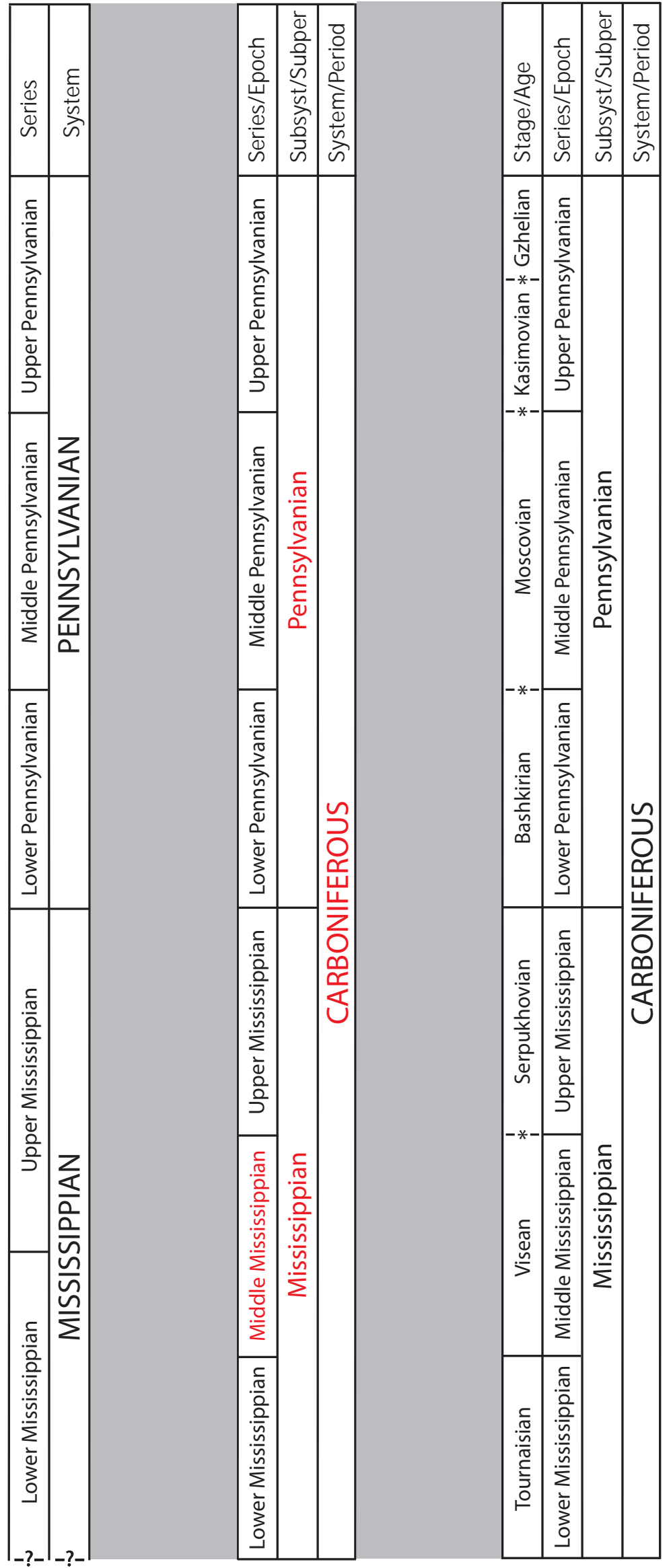

FIGURE 1—Carboniferous nomenclature changes to Zeller (1968) that are formally adopted by the KGS. Left column: Zeller (1968). Center column: This paper, changes are highlighted in red. Right column: ICS nomenclature; stage boundaries with asterisks have not been ratified by the ICS/IUGS. 
Lower Pennsylvanian $=$ Bashkirian; Middle Pennsylvanian = Moscovian; and Upper Pennsylvanian = Kasimovian plus Gzhelian.

Global Stratotype Sections and Points (GSSPs) have been established for the base of the Tournaisian Stage/Age (and coincident base of the Lower Mississippian Series/Epoch, Mississippian Subsystem/Subperiod, and Carboniferous System/ Period) (Paproth et al., 1991; also see the discussion about biostratigraphic problems associated with this GSSP in Kaiser, 2009); the Visean Stage/Age (and coincident base of the Middle Mississippian Series/Epoch) (Work, 2008; Ogg et al., 2008); and the base of the Bashkirian Stage/Age (and coincident base of the Lower Pennsylvanian Series/Epoch and Pennsylvanian Subsystem/Subperiod) (Lane et al., 1999; Richards et al., 2002). GSSPs are still pending for the base of the Serpukhovian, Moscovian, Kasimovian, and Gzhelian stages/ages. More information on Carboniferous GSSPs is available at http:// stratigraphy.science.purdue.edu/gssp.
Regional stage/age names are still valid in the regions in which they were developed (Heckel and Clayton, 2006a, 2006b; Ogg et al., 2008) until all of the international stage/age names are officially ratified and correlations of these boundaries into the regions have been established.

In Kansas, the regional stage/age names (in ascending order, Kinderhookian, Osagean, Meramecian, and Chesterian in the Mississippian Subsystem/Subperiod; and Morrowan, Atokan, Desmoinesian, Missourian, and Virgilian in the Pennsylvanian Subsystem/Subperiod) are retained; their global equivalents, however, can only be approximated at this time. Heckel and Clayton (2006a, fig. 1, p. 404), Heckel and Clayton (2006b, fig. 1, p. 394), and Ogg et al. (2008, fig. 8.6, p. 81) show the approximate equivalency of global stage boundaries to regional stage boundaries in North America (fig. 2). With the KGS now recognizing a Middle Mississippian Series/Epoch, it is important to note that, currently, the Middle Mississippian is thought to include the upper Osagean, Meramecian, and lower Chesterian stages/ages (Heckel and Clayton, 2006a, 2006b; Ogg et al., 2008).

\section{Summary of Formally Adopted Carboniferous Stratigraphic Nomenclature Changes}

The following changes are adopted by the Kansas Geological Survey. Zeller (1968) is modified accordingly (see fig. 1).

1. Carboniferous will be the system/period name for the strata in Kansas between the Devonian and Permian Systems/Periods.

2. Mississippian and Pennsylvanian will be subdivisions of the Carboniferous in Kansas and have the rank of subsystem/subperiod.
3. The Mississippian Subsystem/Subperiod contains three series: Lower, Middle, and Upper Mississippian. Corresponding epochs are Early, Middle, and Late Mississippian.

4. The Pennsylvanian Subsystem/Subperiod contains three series: Lower, Middle, and Upper Pennsylvanian. Corresponding epochs are Early, Middle, and Late Pennsylvanian.

\begin{tabular}{|c|c|c|c|c|}
\hline 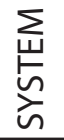 & 品岕 & $\begin{array}{l}\text { GLOBAL } \\
\text { SERIES }\end{array}$ & GLOBAL STAGE & $\begin{array}{l}\text { Regional Stage } \\
\text { North America }\end{array}$ \\
\hline \multirow{9}{*}{ 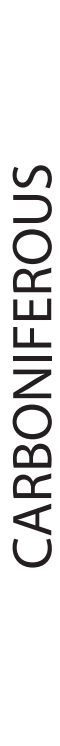 } & \multirow{5}{*}{ 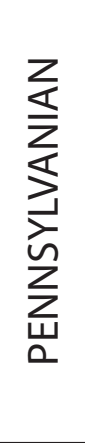 } & \multirow{2}{*}{ UPPER } & GZHELIAN & Virgilian \\
\hline & & & KASIMOVIAN & Missourian \\
\hline & & \multirow{2}{*}{ MIDDLE } & \multirow{2}{*}{ MOSCOVIAN } & Desmoinesian \\
\hline & & & & Atokan \\
\hline & & LOWER & BASHKIRIAN & Morrowan \\
\hline & \multirow{4}{*}{$\begin{array}{l}z \\
\frac{z}{n} \\
\frac{n}{n} \\
\frac{n}{n} \\
\cong\end{array}$} & UPPER & SERPUKHOVIAN & Chesterian \\
\hline & & \multirow[t]{2}{*}{ MIDDLE } & \multirow[t]{2}{*}{ VISEAN } & Meramecian \\
\hline & & & & Osagean \\
\hline & & LOWER & TOURNAISIAN & Kinderhookian \\
\hline
\end{tabular}

FIGURE 2-Approximate equivalency of global subdivisions to regional stage subdivisions in North America (specifically midcontinent United States) (modified from Heckel and Clayton, 2006a, fig. 1, p. 404; and Heckel and Clayton 2006b, fig. 1, p. 394). The position of the MoscovianKasimovian boundary (dashed line) has been uncertain, but recent work (Villa and Task Group, 2008) suggests the boundary may be close to the Desmoinesian-Missourian boundary level. 


\section{References}

Cheney, M. G., Dott, R. H., Hake, B. F., Moore, R. C., Newell, N. D., Thomas, H. D., and Tomlinson, C. W. (Association Subcommittee on Carboniferous), 1945, Classification of Mississippian and Pennsylvanian rocks of North America: Bulletin of the American Association of Petroleum Geologists, v. 29, no. 2, p. 125-169.

Heckel, P. H., and Clayton, G., 2006a, The Carboniferous System-Use of the new official names for the subsystems, series, and stages: Geologica Acta, v. 4, no. 3, p. 403-407.

Heckel, P. H., and Clayton, G., 2006b, Use of the new official names for the subsystems, series, and stages of the Carboniferous System in international journals: Proceedings of the Geologists’ Association, v. 117, pt. 4, p. 393-396.

Kaiser, S. I., 2009, The Devonian/Carboniferous boundary stratotype section (La Serre, France) revisited: Newsletters on Stratigraphy, v. 43, no. 2, p. 195-205.

Lane, H. R., Brenckle, P. L., Baesemann, J. F., and Richards, B., 1999, The IUGS boundary in the middle of the Carboniferous-Arrow Canyon, Nevada, USA: Episodes, v. 22, no. 4, p. 272-283.

Metcalfe, I., 2000, Secretary/Editor's report 1999-2000: Newsletter on Carboniferous Stratigraphy, v. 18, p. 2-3.

Moore, R. C., 1935, Stratigraphic classification of the Pennsylvanian rocks of Kansas: Kansas Geological Survey, Bulletin 22, 256 p.
North American Commission on Stratigraphic Nomenclature, 2005, North American stratigraphic code: American Association of Petroleum Geologists, Bulletin, v. 89, p. 1,547-1,591.

Ogg, J. G., Ogg, G., and Gradstein, F. M., 2008, The concise geologic time scale: Cambridge University Press, 177 p.

Paproth, E., Feist, R., and Flajs, G., 1991, Decision on the DevonianCarboniferous boundary stratotype: Episodes, v. 14, no. 4, p. 331-336.

Richards, B. C., Lane, H. R., and Brenckle, P. L., 2002, The IUGS MidCarboniferous (Mississippian-Pennsylvanian) global boundary stratotype section and point at Arrow Canyon, Nevada, USA; in, Carboniferous and Permian of the World, L. V. Hills, C. M. Henderson, and E. W. Bamber, eds.: Canadian Society of Petroleum Geologists, Memoir 19, p. 802-831.

Villa, E., and Task Group, 2008, Progress report of the Task Group to establish the Moscovian-Kasimovian and Kasimovian-Gzhelian boundaries: Newsletter on Carboniferous Stratigraphy, v. 26, p. $12-13$.

Work, D. M., 2008, Secretary/Editor's report 2007-2008: Newsletter on Carboniferous Stratigraphy, v. 26, p. 4.

Work, D. M., 2004, Secretary/Editor's report 2003-2004: Newsletter on Carboniferous Stratigraphy, v. 22, p. 4-5.

Zeller, D. E., ed., 1968, The stratigraphic succession in Kansas: Kansas Geological Survey, Bulletin 189, 81 p., 1 plate.

\section{KGS Stratigraphic Nomenclature Committee}

This paper was completed by current members of the Kansas Geological Survey's Stratigraphic Nomenclature Committee, which was re-established in July 2005 to address stratigraphic issues and establish formally accepted stratigraphic nomenclature for Kansas. The Stratigraphic Nomenclature Committee is the official arbiter of stratigraphic nomenclature and issues in Kansas, subject to review by the State Geologist. More information about the Committee and Kansas stratigraphic nomenclature is available at http://www.kgs. ku.edu/General/Strat/index.html.

The Kansas Geological Survey (KGS) recognizes Zeller (1968) as the current accepted guide and chart for Kansas. Nomenclature changes will follow the North American Stratigraphic Code (2005), and changes will conform to international stratigraphic nomenclature standards as they apply to Kansas.

\section{Acknowledgments}

Paul Enos, Phil Heckel, and Tom Thompson provided careful, constructive reviews of the manuscript, and we are grateful for their time and expertise. Marla Adkins-Heljeson is thanked for editorial and publication assistance. 